\title{
Sedimentological, geochemical and palaeontological evidence for a neoglacial cold event during the late Holocene in the continental shelf of the northern South Shetland Islands, West Antarctica
}

\author{
Kyu-Cheul Yoo, ${ }^{1}$ Ho Il Yoon, ${ }^{2}$ Jin-Kyung Kim ${ }^{2}$ \& Boo-Keun Khim ${ }^{3}$ \\ 1 School of Earth and Environmental Sciences, Seoul National University, Seoul 151-747, Korea \\ 2 Korea Polar Research Institute, Songdo Techno Park, 7-50, Inchon, Korea \\ 3 Division of Earth Environmental System, Pusan National University, Busan 609-735, Korea
}

\section{Keywords}

Antarctic Peninsula; continental shelf; diatom assemblages; gravity core; Little Ice Age; recent warming

\section{Correspondence}

Ho II Yoon, Korea Polar Research Institute, Songdo Techno Park, 7-50, Inchon, Korea. E-mail: hiyoon@kopri.re.kr

doi:10.1111/j.1751-8369.2009.00109.x

\begin{abstract}
Two sediment cores obtained from the continental shelf of the northern South Shetland Islands, West Antarctica, consist of: an upper unit of silty mud, bioturbated by a sluggish current, and a lower unit of well-sorted, laminated silty mud, attributed to an intensified Polar Slope Current. Geochemical and accelerator mass spectrometry ${ }^{14} \mathrm{C}$ analyses yielded evidence for a late Holocene increase in sea-ice extent and a decrease in phytoplankton productivity, inferred from a reduction in the total organic carbon content and higher $\mathrm{C}: \mathrm{N}$ ratios, at approximately 330 years B.P., corresponding to the Little Ice Age. Prior to this, the shelf experienced warmer marine conditions, with greater phytoplankton productivity, inferred from a higher organic carbon content and $\mathrm{C}: \mathrm{N}$ ratios in the lower unit. The reduced abundance of Weddell Sea ice-edge bloom species (Chaetoceros resting spores, Fragilariopsis curta and Fragilariopsis cylindrus) and stratified cold-water species (Rhizosolenia antennata) in the upper unit was largely caused by the colder climate. During the cold period, the glacial restriction between the Weddell Sea and the shelf of the northern South Shetland Islands apparently hindered the influx of ice-edge bloom species from the Weddell Sea into the core site. The relative increases in the abundance of Actinocyclus actinochilus and Navicula glaciei, indigenous to the coastal zone of the South Shetland Islands, probably reflects a reduction in the dilution of native species, resulting from the diminished influx of the ice-edge species from the Weddell Sea. We also document the recent reduction of sea-ice cover in the study area in response to recent warming along the Antarctic Peninsula.
\end{abstract}

The Holocene was not a period of continual warming and glacial retreat. Rather, there were episodes of neoglacial expansion and retreat, which had significant effects on regional climate and human activities. The most recent cooling and glacial advance marked the start of the Little Ice Age (LIA), which culminated between the mid-1500s and the mid-1800s (Lamb 1977; Grove 1988). The best available evidence for glacier advance and/or atmospheric cooling in the Southern Hemisphere during the LIA has been documented in ice cores from the Peruvian Andes (Thompson et al. 1986), in ice cores from the South Pole (Mosley-Thompson \& Thompson 1982) and from moraines and tills in the Antarctic Peninsula region
(Clapperton \& Sugden 1989; Clapperton 1990). Less agreement exists concerning the cooling conditions of the LIA in the Antarctic Peninsula region. Oxygen isotope data from an ice core from Siple Station in the Antarctic Peninsula suggest that warmer conditions existed at the time of the LIA, and provide a local impression of Holocene climate variability (Mosley-Thompson et al. 1990). For the Antarctic marine environment there are few data concerning the LIA, excepting the evidence of ice-shelf advance and sea-ice increase over this time period (Domack et al. 1995; Shevenell et al. 1996).

We studied gravity and box sediment cores collected from the continental shelf of the northern South 
Shetland Islands, on the Antarctic Peninsula, to reconstruct the late Holocene cold event, associated with variable sea-ice conditions (Fig. 1). Influencing biological productivity, aeolian flux and terrrigenous sediment discharge, sea ice is an important glaciological feature around the periphery of the Antarctic continent. Sea ice is often associated with the cold polar climate of the Antarctic, and, in general, is controlled by mean annual temperature and intrusion of circumpolar deep water (CDW) from the Antarctic Circumpolar Current (ACC). Hence, sea ice and associated biological production on the northern Antarctic Peninsula shelf may represent sensitive climatic indicators, and the fluctuations of such features in the past may provide us with important palaeoenvironmental information.

\section{Methods}

\section{Sediment sampling}

The sediment cores WB1 and WB2 were collected from an inner shelf and a deep trough on the outer shelf of the northern South Shetland Islands, respectively, using a gravity corer and a box corer (Fig. 1). The box corer provides an excellent means to study recent sedimentation changes, because it preserves an intact sedimentwater interface. Gravity cores are also likely to capture the modern sediment-water interface, as we found when the $\mathrm{X}$-radiographs from the two different cores were examined.

\section{Laboratory analyses}

The cores were cut lengthwise in the laboratory: one half was visually described and sliced for X-radiographs, and the other half was used for subsampling. Subsamples were taken at every $2 \mathrm{~cm}$ down the length of the cores, to determine grain size, and total organic carbon (TOC) and total inorganic carbon (TIC) contents. The total carbon (TC) and total nitrogen (TN) contents were analysed with a FLASH EA 1112 CHNS-O Automatic Element Analyzer (Thermo Finnigan, now Thermo Scientific, Waltham, MA, USA). The TIC content was determined with a carbon dioxide coulometer, model 5030, with an acidification unit (UIC Inc., Joliet, IL, USA). The TOC content was calculated by subtracting TIC from TC. The grain size distribution for the size fractions from -4.0 to $4.0 \phi$, where $\phi=-\log _{2} D / D_{0}$, and $D$ is the diameter of the particle and $D_{0}$ is the reference diameter, which is set to $1 \mathrm{~mm}$, of core WB2 was analysed by dry sieving. The finer fractions (from 4.0 to $10.0 \varphi$ ) were analysed with a SediGraph 5000 D (Micromeritics Instrument Corporation, Norcross, GA, USA). The method for computing raw data is described in Jones et al. (1988), and the classification of sediments followed the scheme of Folk \& Ward (1957). Physical and biogenic sedimentary structures were revealed through $\mathrm{X}$-radiographs of $\mathrm{l}$-cm-thick sediment slabs. To measure the anisotropy of magnetic susceptibility for the cores, cubic specimens were collected by pushing non-magnetic plastic boxes into the surface of the halved core. A low-field $(0.47-\mathrm{kHz})$ MS2 magnetic susceptibility meter connected to an MS2B sensor (Bartington Instruments, Witney, Oxon, UK) was used for measuring the anisotropy of magnetic susceptibility. Measurements at 24 positions for each specimen were performed to determine the magnitude and directions of the maximum $\left(k_{1}\right)$, intermediate $\left(k_{2}\right)$ and minimum $\left(k_{3}\right)$ axes of the anisotropy of magnetic susceptibility. To evaluate the relationship between the bottom current intensity and the magnetic fabric in the sedimentary records, the alignment parameter (Fs) of the anisotropy of magnetic susceptibility was calculated from the following equation (Ellwood 1975).

$$
F s=k_{1}^{2} /\left(k_{2}^{2} \times k_{3}^{2}\right)^{1 / 2}
$$

Bulk sediment samples from core WB2 were used for accelerator mass spectrometer (AMS) radiocarbon dating. The dating was performed at GNS Science, Lower Hutt, New Zealand. Samples for ${ }^{210} \mathrm{~Pb}$ analyses were collected from the exposed core WB2, were then dried at the Korea Polar Research Institute for analysis of water content, and were then sent to the Korea Basic Science Institute for further analysis, following the procedures described by DeMaster \& Cochran (1982). Quantitative diatom analyses for core WB2 were performed with a settling method (Scherer 1994). This method can be used to determine the absolute diatom concentration (diatom per gram of sediment). Approximately 500 diatom valves were counted along transects per slide, using a photomicroscope at a magnification of $1250 \times$ (Zeiss, Oberkochen, Germany). Diatom counts were completed following the procedures outlined by Schrader \& Gersonde (1978).

\section{Environmental characteristics}

\section{Climate and sea-ice distribution}

The northernmost Antarctic Peninsula region experiences a slightly more moderate climate (cold temperate to subpolar) compared with the western Antarctic Peninsula, on account of its lower latitude. The mean summer temperature varies from $1.1^{\circ} \mathrm{C}$ (December) to $2.2^{\circ} \mathrm{C}$ (January) with a mean summer relative humidity of $89 \%$, resulting in great surface melting and run-off. The late-summer snowlines around the South Shetland Islands are about $150 \mathrm{~m}$ a.s.l. The basal ice temperatures 


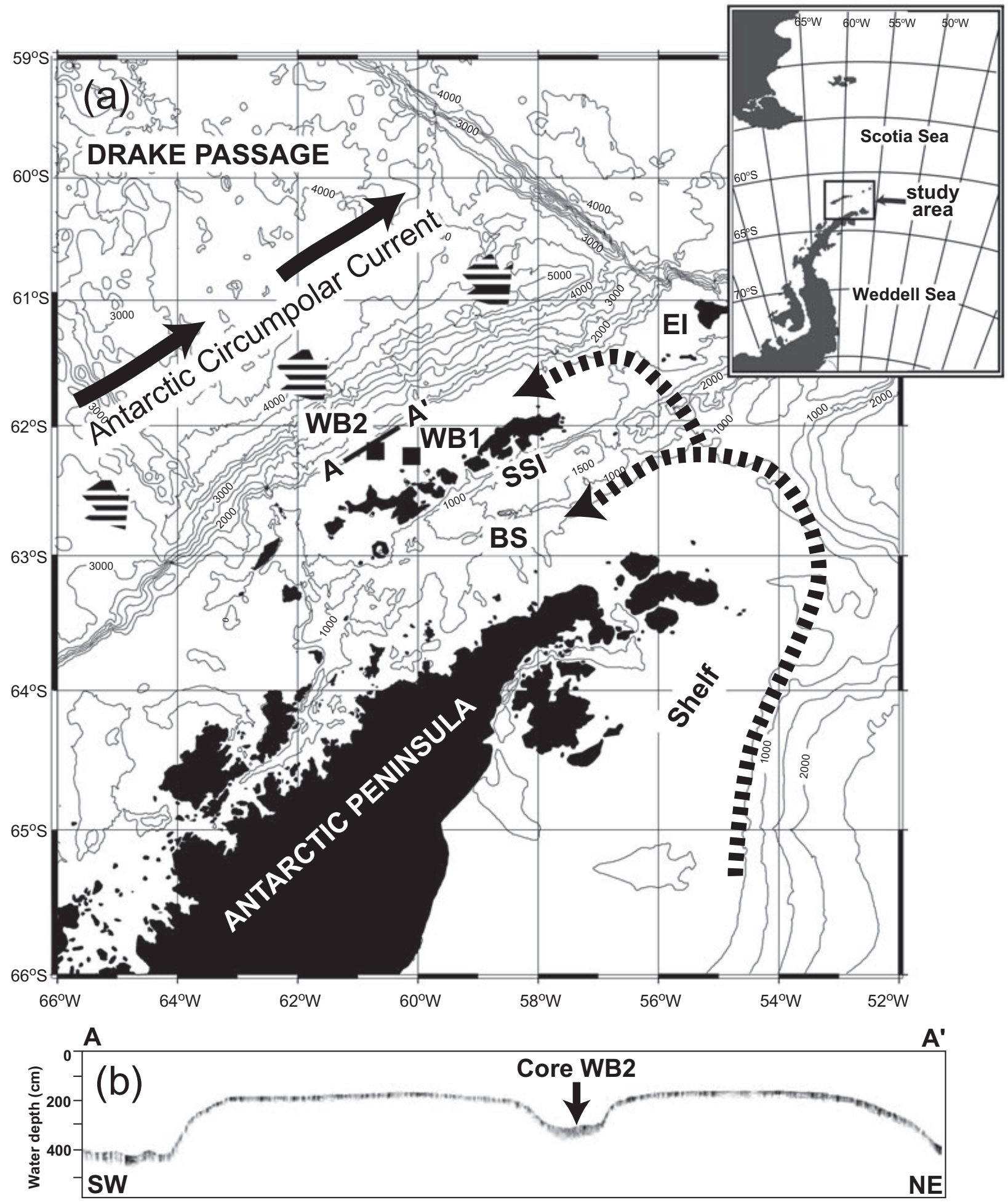

Fig. 1 (a) Map of the northern Antarctic Peninsula continental shelf and north-west Weddell Sea, schematically showing the domains flow paths of the principal water masses in the region. The heavy dashed arrows indicate the Polar Slope Current of Weddell Sea water origin, which is a mixture of shelf waters from the north-west Weddell Sea. The heavy solid arrows represent the Antarctic Circumpolar Current, from which Circumpolar Deep Water (short hatched arrows) moves up to the continental shelf region in the study area. Solid squares show the locations of cores WB1 and WB2. The bathymetry is indicated in metres. Abbreviations: BS, Bransfield Strait; El, Elephant Island; SSI, South Shetland Islands. (b) High-resolution (3.5-kHz) seismic profile from the outer continental shelf of the northern South Shetland Islands. The location of core WB2 is noted in the trough. 
are unknown, but may be at the pressure melting point near glacier termini, as basal temperatures in glaciers further south are known to be at the pressure melting point (Smith 1972). Regional atmospheric warming is demonstrated by a comparison of aerial photographs of Marian Cove, a tributary embayment of Maxwell Bay, in the southern South Shetland Islands, which shows that the extent of glacier retreat between 1989 and 1994 was approximately the same as the retreat during the preceding 30 years (1956-1986) (Park et al. 1998). The annual total rainfall is approximately $17 \mathrm{~cm}$, and rainfall during the austral summer (from December to February) accounts for $73 \%$ of the total annual rainfall. The annual total snowfall is approximately $460 \mathrm{~cm}$ in water equivalent, and the monthly total snowfall has a maximum value of $230 \mathrm{~cm}$ in June.

Although information about sea ice on the shelf of the northern South Shetland Islands is lacking, pack ice begins to form in Maxwell Bay in the southern islands in August, and from late October it rapidly breaks up and the bay soon becomes completely ice-free, giving rise to increased biological productivity. Modern bays and fjords in the South Shetland Islands frequently remain ice-free throughout the whole year as a result of the recent regional atmospheric warming.

\section{Oceanography}

The continental margin of the northern South Shetland Islands is influenced by the relatively warm $\left(1-2^{\circ} \mathrm{C}\right)$ CDW, with a salinity range of 34.3-34.8 psu, that is transported from the south-west, with the ACC and the cold Polar Slope Current of Weddell Sea origin (Tokarczyk 1987) (Fig. la). In particular, on the continental shelf of the northern islands, where the present cores were collected, a westward Polar Slope Current is predominant, with eddies forming along the shelf break, whereas CDW, derived from the ACC, is confined mostly to the oceanic zone, and does not extend onto the shelf (Ichii et al. 1998). The Polar Slope Current is a narrow (ca. $20 \mathrm{~km}$ wide) and cold (less than $2^{\circ} \mathrm{C}$ ) current, lying at a depth of $300 \mathrm{~m}$ along the shelf break and upper slope of the northern South Shetland Islands. This current, which is thought to originate in the Weddell Sea, flows counter (i.e., westward) to the prevailing surface current (northeastward) of this region (Hofmann et al. 1992), carrying Weddell Sea water to the west. The Polar Slope Current has also been suggested as a mechanism for transporting krill embryos released north of the South Shetland Islands to the west. Whitworth et al. (1994) characterized the Polar Slope Current as a shelf-water mixture derived principally from the isopycnal mixing of the waters of the ACC with waters of the Weddell Sea, and reported surface water temperatures ranging from -1.6 to $1.5^{\circ} \mathrm{C}$, and salinity in the range of 33.0-34.6 psu.

\section{Glacial history}

There is much debate on the Holocene glacial and palaeoclimatic history of the South Shetland Islands. Mäusbacher et al. (1989) reported that the deglaciation of King George Island occurred between 9000 and 5000 years B.P., based on the dating of lake sediments. According to ${ }^{14} \mathrm{C}$ dates of marine sediments, the recent deglaciation from Marian Cove occurred sometime later than 1300 years B.P. (Yoon et al. 1997). More details on the mid-Holocene history of the South Shetland Islands were presented by Bjorck, Hakansson et al. (1991), who concluded that a climatic optimum occurred between 3200 and 2700 years B.P. in Midge Lake on Byers Peninsula, an estimate that is in agreement with the moss bank data from Elephant Island (Bjorck, Malmer et al. 1991). The moss bank data also suggest colder conditions at 5500-4300 and 3900-3200 years B.P., and an additional mild period at 4150-3900 years B.P. They also think that such humid conditions could have caused a readvancement of the glaciers on King George Island about 3000 years B.P. (Barsch \& Mäusbacher 1986; Mäusbacher et al. 1989). Schmidt et al. (1990) attributed the increased allochthonous input to lakes to climatic change between 4700 and 3200 years B.P.

\section{Radiocarbon data}

The AMS ${ }^{14} \mathrm{C}$ age is based on four samples of bulk organic matter from core WB2 (Table 1). The ${ }^{14} \mathrm{C}$ age from surface $(0-1 \mathrm{~cm})$ sediments of the core was measured as $2642 \pm 35$ years B.P., which is somewhat older than the accepted ocean reservoir correction for Antarctica (12001400 years B.P.; Berkman et al. 1998; Ingolfsson et al. 1998). This could suggest that the core-top materials are missing as much as $3.6 \mathrm{~m}$ (1241 years) from the sediment-water surface. However, radiocarbon dating

Table 1 Results of the accelerator mass spectrometer (AMS) ${ }^{14} \mathrm{C}$ dating of core WB2.

\begin{tabular}{clrlll}
\hline $\begin{array}{c}\text { Core depth } \\
(\mathrm{cm})\end{array}$ & \multicolumn{2}{l}{ Age $\left({ }^{14} \mathrm{C}\right.$ years B.P. $)$} & & \\
\cline { 2 - 3 } & Uncorrected & Corrected $^{\text {an }}$ & Material & Lab. code \\
\hline 0 & $2642 \pm 35$ & $0 \pm 35$ & bulk sediment & NZA19176 \\
132 & $3101 \pm 40$ & $459 \pm 40$ & bulk sediment & NZA19178 \\
198 & $3419 \pm 40$ & $777 \pm 40$ & bulk sediment & NZA19382 \\
266 & $4186 \pm 35$ & $1544 \pm 35$ & bulk sediment & NZA19383 \\
\hline
\end{tabular}

${ }^{\mathrm{a}} \mathrm{A} 2642$-year correction was applied to all ages of core WB2. This correction appears to be justified because all of the radiocarbon ages in the core were thoroughly contaminated by the reworked older carbon, as seen in Table 2. 
Table 2 Reworked dinoflagellate cysts from core WB2.

\begin{tabular}{lccl}
\hline Species & Core depth $(\mathrm{cm})$ & Number $^{\text {a }}$ & Range \\
\hline Trityrodinium vermiculata & 2 & 9 & Upper Cretaceous \\
Lingulodinium machaerophorum & 2 & 10 & \\
Nelsoniella sp. & 90 & 14 & Upper Cretaceous \\
Trityrodinium vermiculata & 90 & 9 & Upper Cretaceous \\
Lingulodinium machaerophorum & 100 & 18 & \\
Amphidiadema denticulate & 100 & 19 & Upper Cretaceous \\
Operculodinium israelianum & 160 & 19 & \\
Operculodinium israelianum & 200 & 20 & \\
Trityrodinium vermiculata & 200 & 18 & Upper Cretaceous \\
Cribrodinium giuseppi & 240 & 20 & Cretaceous \\
Cribrodinium giuseppi & 245 & 23 & Cretaceous \\
Bering fritilla & 255 & 20 & \\
Operculodinium israelianum & 255 & 20 & \\
\hline
\end{tabular}

${ }^{a}$ The number of reworked species per 150 dinoflagellate cysts.

has frequently resulted in such anomalously old modern surface ages for organic matter from the Antarctic. In a previous study (Yoon et al. 2002), we obtained AMS ${ }^{14} \mathrm{C}$ ages ranging between $3690 \pm 55$ and $3120 \pm 50$ years B.P. for the surface sediments on the mid- and outer continental shelves off the Anvers and Brabant islands, $600 \mathrm{~km}$ south-west of core WB2. Domack and coworkers (Domack et al. 1989; Domack et al. 1991) also observed a range for the surface sediments on the East Antarctica continental shelf from $1915 \pm 50$ to $5020 \pm 180$ years B.P., which is older than the expected reservoir correction of 1200 years B.P. (Gordon \& Harkness 1992). Pudsey $\&$ Evans (2001) also reported an old surface age (about $6000{ }^{14} \mathrm{C}$ years B.P.) in the Weddell Sea. The old AMS age of surface sediments in the Antarctic has been attributed to old carbon contamination, caused either by the liberation of $\mathrm{CO}_{2}$ stored in the ice sheets (Domack et al. 1989), along with the uptake of "old" dissolved inorganic carbon by recycled ancient organic matter (i.e., diatoms; Gibson et al. 1999), or by the assimilation of dissolved inorganic carbon by diatoms during $\mathrm{CO}_{2}-$ limiting conditions (Tortell et al. 1997). Thus, the rather old surface age of $2642{ }^{14} \mathrm{C}$ years B.P. for core WB2 is neither surprising nor unreasonable, and does not indicate that the top of core WB2 was missing when the coring apparatus touched the sea bottom. Because Cretaceous dinoflagellate cysts are commonly observed in core WB2, the old age of the top of the core can be explained by the incorporation of reworked and older organic matter delivered by a strong bottom current (Table 2). A strong shelf-to-slope current from the Weddell Sea is known to play a role in influencing the current system on the northern shelf of the South Shetland Islands (Whitworth et al. 1994).

To derive a chronology for core WB2, we have used a couple of approaches.
First, we assumed that the surface age indicates the present-day conditions. Thus, we used the ${ }^{14} \mathrm{C}$ age $(2640$ years B.P.) that we obtained as a correction, and subtracted it from the three measured ages lower down in the core, as has been done in previous studies in the Antarctic (Domack et al. 2001; Pudsey \& Evans 2001; Allen et al. 2005). The determination of this correction appears to be justified because: (1) recycled Cretaceous organic matter is apparent throughout the core from smear slides (Table 2), and (2) all of the measured radiocarbon ages in core WB2 increase progressively with depth throughout the core, reflecting that the contamination is consistent (Table 1).

Second, the corrected radiocarbon data were used to estimate the age versus depth relationships in the study area. The age-depth model shows that the sedimentation rate of core WB2 varied from $0.29 \mathrm{~cm} \mathrm{yr}^{-1}$ in the upper part of the core to $0.10-0.21 \mathrm{~cm} \mathrm{yr}^{-1}$ in the lower part, with a maximum core age of 4200 years B.P. (Fig. 2a). The sedimentation rate in core WB2 seems to be at least four times faster than that reported from a fjord setting in the Antarctic Peninsula (Lallemand Fjord, 0.06$0.08 \mathrm{~cm} \mathrm{yr}^{-1}$ [Shevenell et al. 1996]), and two times the sedimentation rates reported from the Palmer Deep (0.17 $\mathrm{cm} \mathrm{yr}^{-1}$ [Domack et al. 2001]). Such a high sedimentation rate on the Antarctic shelf may be inferred from a high-resolution $(3.5-\mathrm{kHz})$ seismic profile, which clearly shows that core WB2 was collected from the centre of one of the troughs that has developed along the shelf of the northern South Shetland Islands (Fig. 1b). Yoon et al. (2004) reported numerous deep troughs on the shelf of the South Shetland Islands, and most of them might have been formed by glacial erosion during the advancement of a grounding glacier on the northern islands during the Last Glacial Maximum (LGM). As the glacial margin retreated landwards after the LGM, dense 

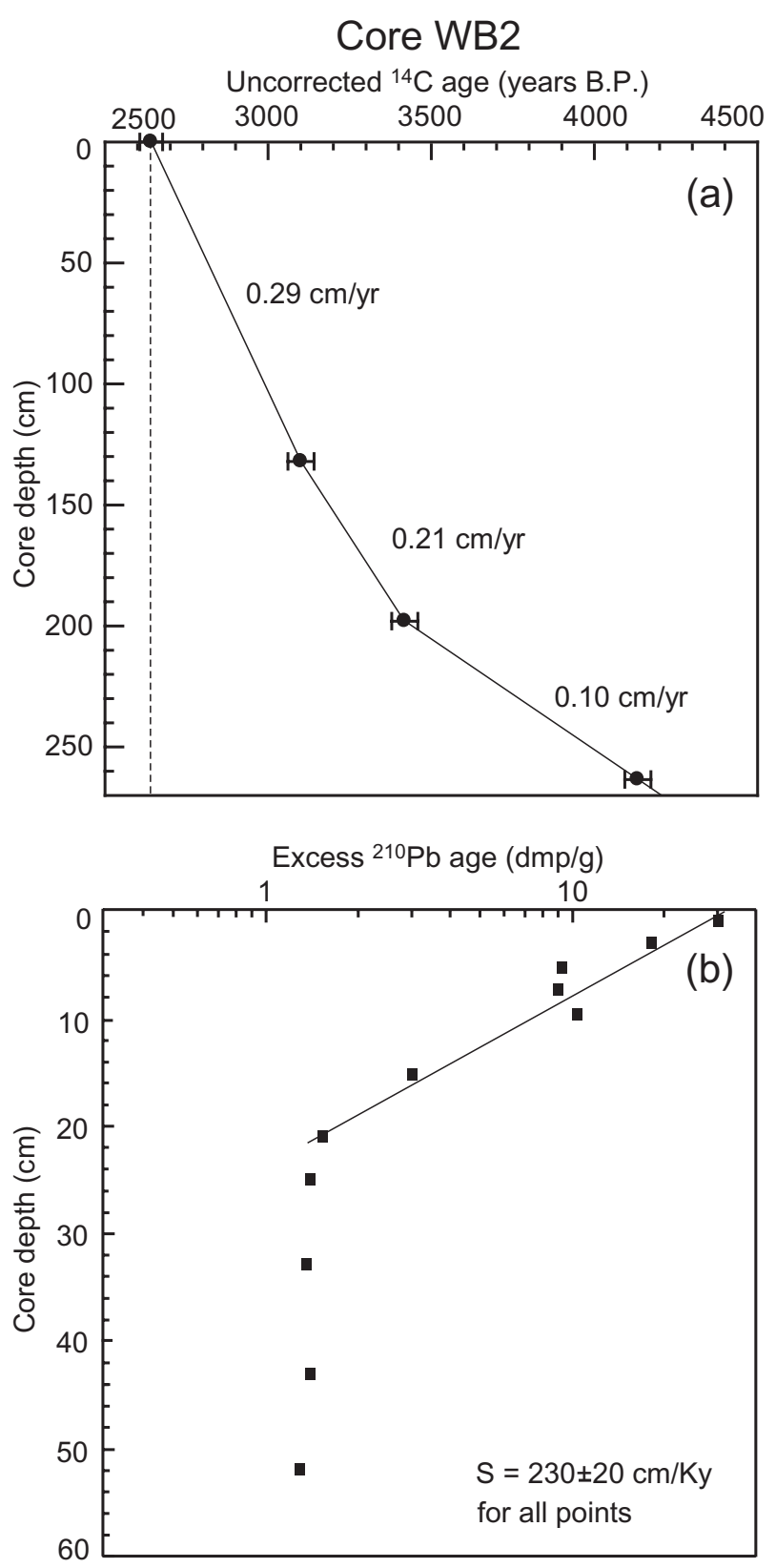

Fig. 2 (a) Estimated sedimentation rate of core WB2 based on uncorrected radiocarbon ages and chronology. (b) Sedimentation rate of core WB2 based on down-core ${ }^{210} \mathrm{~Pb}$ activity.

meltwater plumes released from the retreating ice-front were funnelled along the glacier-carved troughs, with channel-fill deposits accumulating on the shelf, probably resulting in the unusually high sedimentation rate.

More chronological information is provided by the ${ }^{210} \mathrm{~Pb}$ analysis for core $\mathrm{WB} 2$. The ${ }^{210} \mathrm{~Pb}$ profile for the core represents an excess of ${ }^{210} \mathrm{~Pb}$ activity in the upper $20 \mathrm{~cm}$ of the core, below which the activity is in equilibrium with other radionuclides (Fig. 2b), which allow us to interpret the core top of WB2 as belonging to the last 80 years. This indicates that the top $30 \mathrm{~cm}$ of core WB2 (corresponding to the end of the LIA, at 100 years B.P. on the Antarctic Peninsula) could not have been lost during the coring process. The ${ }^{210} \mathrm{~Pb}$ profile also shows an average sedimentation rate of $0.23 \mathrm{~cm} \mathrm{yr}^{-1}$ (Fig. 2b), which is within the range of the rates $\left(0.10-0.29 \mathrm{~cm} \mathrm{yr}^{-1}\right)$ calculated from the AMS ${ }^{14} \mathrm{C}$ data. This suggests that the sedimentation rate derived from the AMS ${ }^{14} \mathrm{C}$ data from core WB2 is a reasonable basis for establishing the chronology in this study. Thus, with the sedimentation rate of $0.10-0.29 \mathrm{~cm} \mathrm{yr}^{-1}$, we extrapolate the inferred age of core WB2 for the palaeoclimatic events.

\section{Sedimentology and geochemistry}

Core WB1 was obtained from the inner continental shelf of the northern South Shetland Islands at a water depth of $210 \mathrm{~m}$, whereas core WB2 was from a trough on the outer shelf at a water depth of $345 \mathrm{~m}$ (Fig. 1). The response of core WB2 in a high-resolution $(3.5-\mathrm{kHz})$ seismic profile is a semi-prolonged bottom echo (Fig. lb). This is interpreted as thick (more than $30 \mathrm{~m}$ ) composite channel-fill deposits emplaced by hemipelagic settling particles and intermittent turbid plumes from the grounding line as the glacier front retreated rapidly during the Holocene. Based on the detailed description of the sedimentary structure shown on the X-radiographs, two sedimentary units are classified from the two cores: bioturbated silty mud in the upper unit and laminated silty mud in the lower unit (Figs. 3, 4). In this study, core WB2 was used to produce a multiproxy data set, including magnetic susceptibility, TOC content, $\mathrm{C}: \mathrm{N}$ ratio, grain-size data and diatom assemblage, whereas core WBI was only used to derive X-radiography, magnetic susceptibility and geochemical data, for the purpose of lithologically correlating the two cores (Fig. 3).

\section{Core WB2}

Obtained from the outer trough on the shelf, core WB2 is mainly composed of a silty clay to clay that varies from olive grey, bioturbated silty mud (upper unit; above $100 \mathrm{~cm}$ of the core depth) to greenish grey, laminated silty mud (lower unit; below $100 \mathrm{~cm}$ of the core depth) (Fig. 3). The upper unit is commonly bioturbated, and partly mottled, with a mean grain size of $8.6-10.3 \phi$, except for the top $15 \mathrm{~cm}$, where the mean grain size decreases abruptly (Figs. 4a, 5). The sediments consist primarily of clay-sized material, with $1-3 \%$ composed of poorly sorted sand, although the grain-size maxima are noted in the uppermost $15 \mathrm{~cm}$, where the silt content 


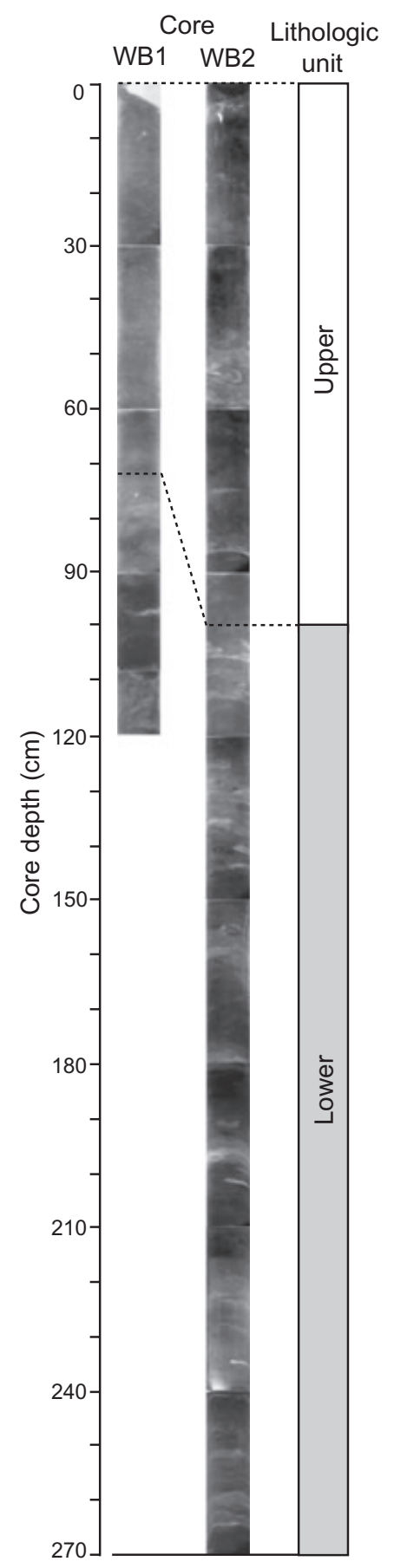

Fig. 3 Facies diagram correlating the cores WB1 and WB2. The correlation is based on the interpretation of physical and biogenic sedimentary structures on the X-radiographs. The core locations are shown in Fig. 1.

increases to more than $40 \%$ (Fig. 5). The increased silt content in the upper $15 \mathrm{~cm}$ tends to co-occur with the maxima of sorting value (well-sorted), and this is also the case in other parts of the core, as seen in Fig. 5. The sediments in the upper unit are also negatively skewed,

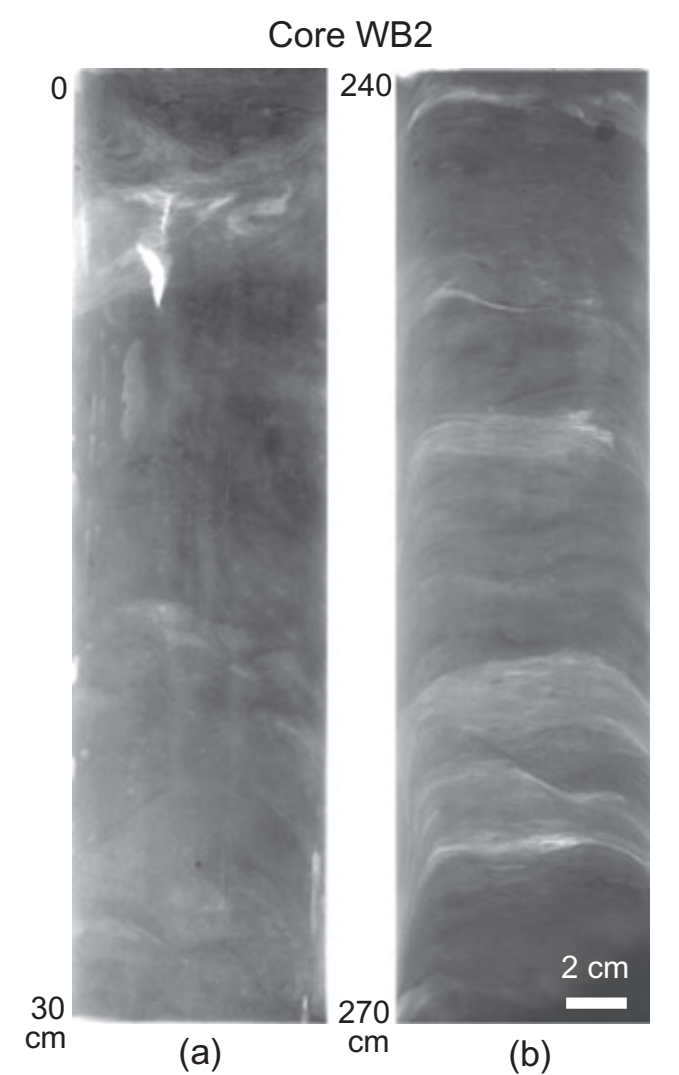

Fig. 4 Representative lithology on X-radiographs of core WB2, from a trough of the outer continental shelf of the northern South Shetland Islands. (a) Bioturbated silty mud in the upper unit, deposited by a sluggish current during a colder climate, and (b) laminated silty mud in the lower unit, attributed to an intensified Polar Slope Current during a period of warmer climate.

with values from -2.4 to -0.5 , except for the top $15 \mathrm{~cm}$, where the sediments tend to be positively skewed (Fig. 5). Fs, which is often used to describe the structure of the bottom current, shows a decreasing trend, ranging from 1.01 to 1.15 in the upper unit (Fig. 5). The TOC content in the upper unit is slightly lower $(0.52-0.71 \%)$ than in the lower unit, excepting for the top $15 \mathrm{~cm}$, where the TOC content dramatically increases (up to $0.9 \%$; Fig. 6). Magnetic susceptibility values are relatively high (400-590 cgs) in the upper unit, compared with the lower unit, and they remain consistently high within the unit (Fig. 6). The $\mathrm{C}: \mathrm{N}$ ratios are also slightly higher in the upper unit, ranging from 7.5 to 12.4 , than in the lower unit (Fig. 6).

The lower unit is laminated or weakly laminated, as seen in the X-radiography (Fig. 4b). Laminae within the unit are formed by millimetre-scale interlamination with greenish grey fine silt. The thin silt laminae are less rhythmically interbedded, and have sharp lower contacts and 


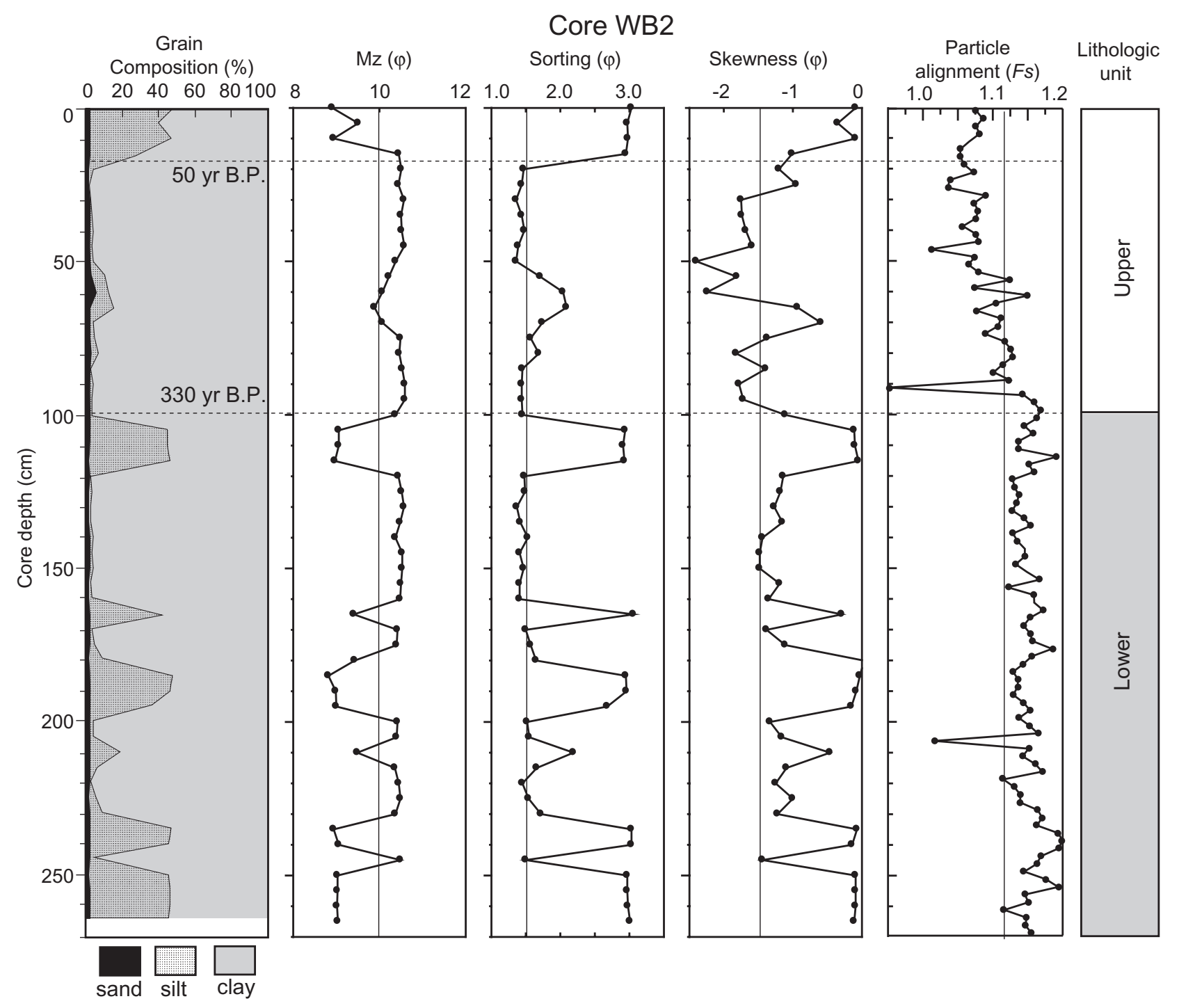

Fig. 5 Down-core variations of grain composition, mean grain size (Mz), sorting $(\phi)$, skewness $(\phi)$ and particle alignment (Fs) of core WB2.

gradational contacts with the thicker mud above (Fig. 4b). The sediments mostly consist of silty clay to clay, with a negligible quantity of sand, and commonly contain well-sorted $(>2.5 \phi)$, silt-rich intervals: the intervals specifically occur at depths of 100-120, 180-200, 230-240 and 250-265 cm, as seen in Fig 5. The sediments in the lower unit are commonly positively skewed (from -1.5 to 0.0 ), with a mean grain size of $8.5-10.4 \phi$ (Fig. 5). The TOC content is slightly higher $(0.57-1.06 \%)$ than in the upper unit, with a maximum concentration at a depth of $210 \mathrm{~cm}$, and fluctuates throughout the unit (Fig. 6). Magnetic susceptibility values, varying from 343 to $552 \mathrm{cgs}$, and $\mathrm{C}: \mathrm{N}$ ratios, varying from 5.1 to 12.3 , are relatively low in the lower unit, and, significantly, fluctuate compared with the upper unit (Fig. 6). The lower unit also shows relatively high Fs values, compared with the upper unit, ranging from 1.01 to 1.21 in the lower unit (Fig. 5).

\section{Core WB1}

Core WB1, collected from the inner shelf, has a downcore pattern of lithologic sequence and geochemical properties that is similar to core WB2 (Figs. 3, 7). It consists largely of an olive grey, bioturbated silt to sandy mud in the upper unit (above $73 \mathrm{~cm}$ of the core depth), and grey, laminated silty mud in the lower unit (below $73 \mathrm{~cm}$ of the core depth) (Fig. 3). As in core WB2, a higher TOC content is commonly observed in the lower unit, ranging from 0.28 to $0.36 \%$, whereas a lower TOC content is 
Fig. 6 Down-core variations of magnetic susceptibility (MS), total organic carbon content (TOC) and $\mathrm{C}: \mathrm{N}$ ratio of core WB2.

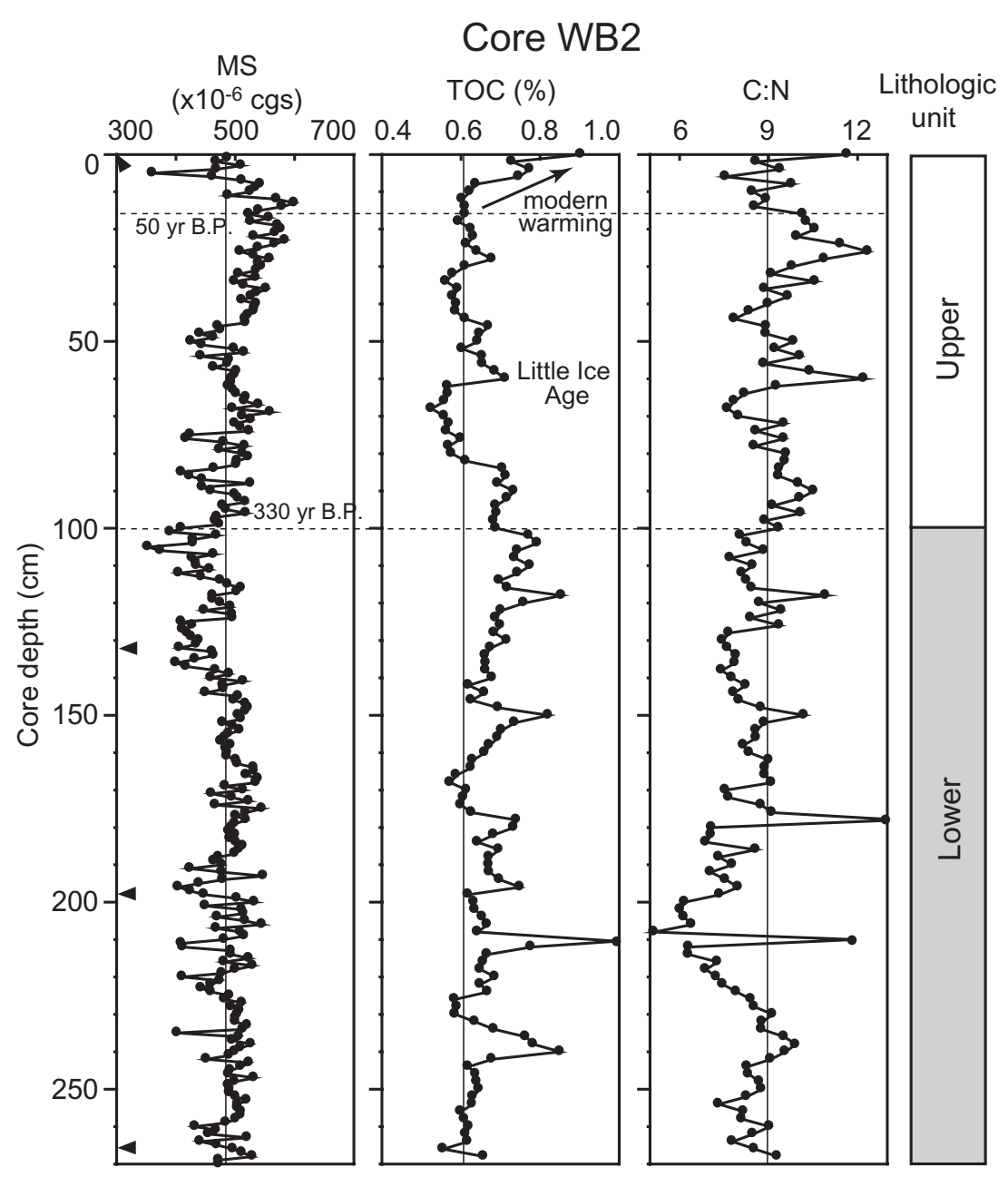

observed in the upper unit, except for the top $22 \mathrm{~cm}$, where the TOC content gradually increases up to $0.41 \%$ (Fig. 7). The C : N ratios are lower, ranging from 6.1 to 13 in the lower unit, and from 9.2 to 18 in the upper unit, except for the top $22 \mathrm{~cm}$, where the ratios gradually decrease (Fig. 7). The magnetic susceptibility values in the lower unit are relatively low (420-900 cgs), compared with the upper unit, except for the top $22 \mathrm{~cm}$, where they decrease abruptly (Fig. 7). The highest values of $F$ s are observed in the lower unit, ranging from 1.07 to 1.15, whereas the lowest values are found in the upper part of the upper unit; however, no significant increase of Fs was observed in the top $22 \mathrm{~cm}$ of core WBl (Fig. 7).

\section{Micropalaeontology}

A total of 27 diatom taxa have been identified from core WB2. Comprising $20-80 \%$ of the total, the dominant species is a Chaetoceros resting spore (Fig. 8). The rest of the assemblage includes taxa such as Fragilariopsis kerguelensis, Fragilariopsis curta and Rhizosolenia antennata (Fig. 8). As the large numbers of Chaetoceros resting spores in the sediment may mask the signal of the rest of the assemblage, we calculated the relative abundance of the rest of the diatoms excluding the Chaetoceros resting spores. Minor components $(<10 \%)$ of the assemblages are Actinocyclus actinochilus, Thalassiosira antarctica, Navicula glaciei and Fragilariopsis cylindrus (Fig. 8).

Floral trends show a distinct change at a depth of $100 \mathrm{~cm}$ in core WB2 (Fig. 8). The number of Chaetoceros resting spore valves per gram of sediment is consistently greater than 2000 valves $\mathrm{g}^{-1}$ in the lower unit, below $100 \mathrm{~cm}$ of the core; above this level, the number decreases (Fig. 8). The abundance changes of total diatom valves parallel those found in Chaetoceros valves in the core, showing decreased diatom valve concentration in the upper unit (Fig. 8). The upper unit is also characterized by a relative decrease in the abundance of sea-ice taxa (F. curta and F. cylindrus), the species most commonly associated with the marginal ice zone (MIZ) of the 


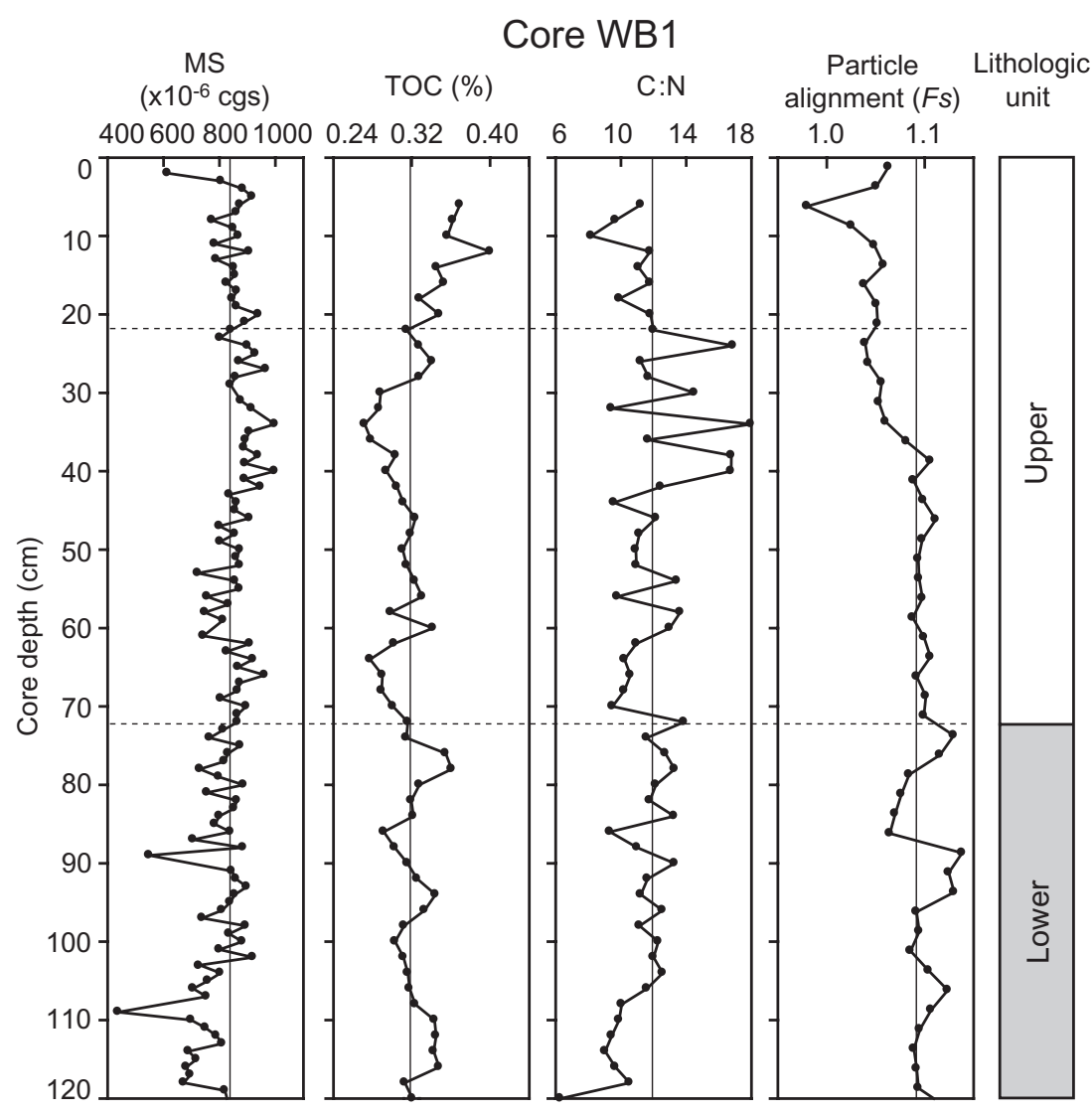

Fig. 7 Down-core variations of magnetic susceptibility (MS), total organic carbon content (TOC) and $\mathrm{C}: \mathrm{N}$ ratio of core WB1.

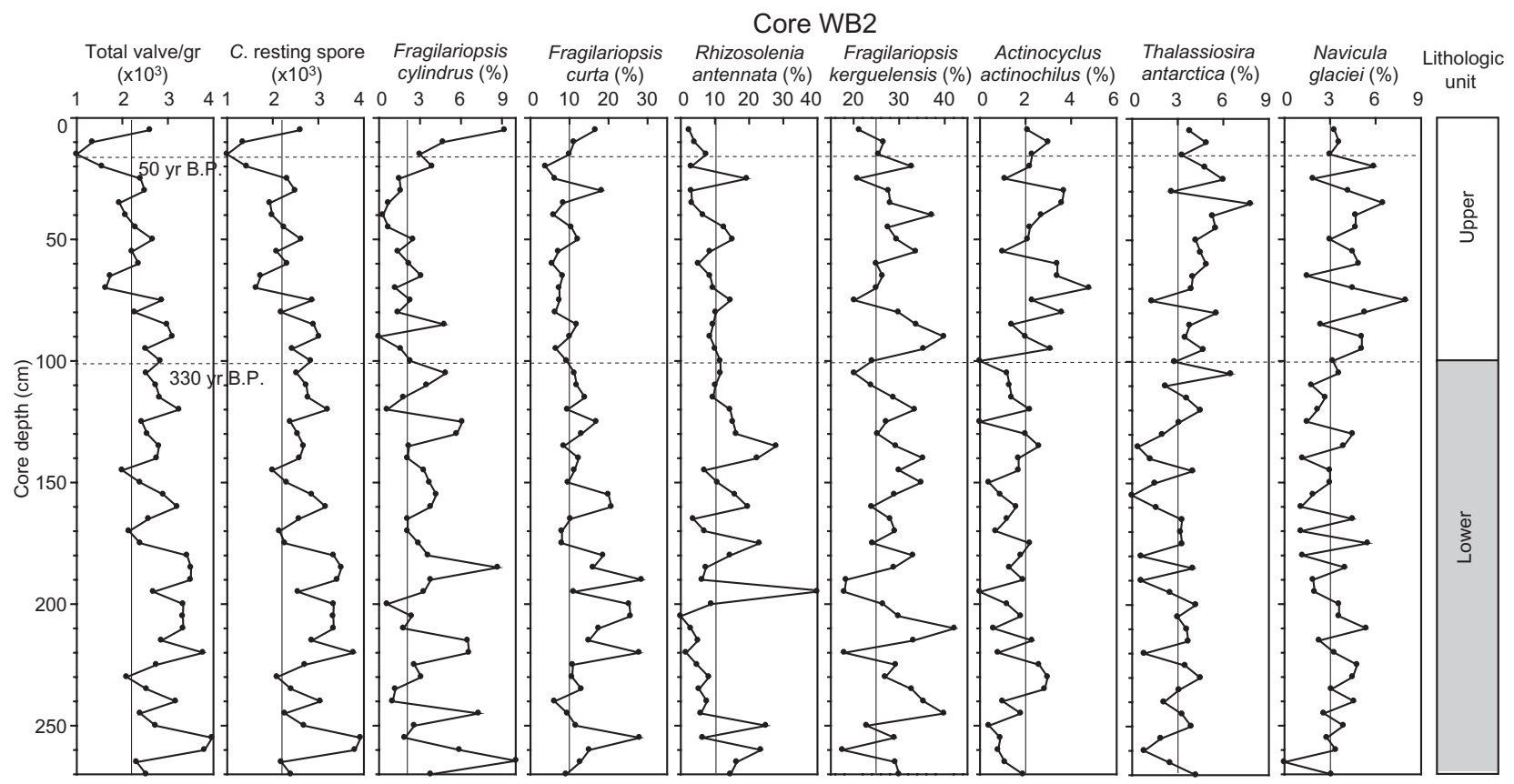

Fig. 8 Down-core variations of diatom assemblages of core WB2. 
north-west Weddell Sea (Kang et al. 2001), and R. antennata, a typical stratified-water species of the Southern Ocean (Crosta et al. 2004). Crosta et al. (2005) analysed 228 modern sediment samples from Atlantic and Indian sectors of the Southern Ocean, and categorized $R$. antennata as a cool open ocean group, with an apparent tolerance to sea-ice conditions. This is followed by the relative increase in the abundance of the taxa A. actinochilus, T. antarctica and N.glaciei in the upper unit (Fig. 8). The planktic, centric A. actinochilus is considered to be a typical Antarctic neritic species (Kozlova 1966) that commonly occurs in the coastal sea-ice zone (Medlin $\delta$ Priddle 1990). It is one of the characteristic species found in the area where sea ice is absent for only two months (Armand et al. 2005). The genus Thalassiosira is widespread in Antarctic waters, where it generally occurs in open water. It is uncommon in sea ice (Fryxell $\&$ Kendrick 1988; Leventer \& Dunbar 1996), which Fryxell et al. (1987) attributed to its inability to survive the low light conditions beneath the sea ice. The observation that T. antarctica is present in some sea-ice samples (Villareal $\delta$ Fryxell 1983; Leventer \& Dunbar 1996), however, has led to the suggestion that it may be associated with coastal sea ice, and zones of loose platelet ice underneath drifting pack ice (Cunningham \& Leventer 1998). N. glaciei has recently been reported to show a maximum abundance in the loose and/or fragile coastal sea ice when sea ice begins to freeze (in April) and thaw (in October) in fjords in the southern South Shetland Islands (Kang et al. 2002).

\section{Interpretation and discussion}

\section{Glaciomarine sedimentation and palaeoclimatic implication}

Two distinct palaeoenvironments may be inferred for the continental shelf of the northern South Shetland Islands during the late Holocene. A number of parameters exhibit strong correlations and represent distinct palaeoenvironments in the shelf. Two sediment cores, based upon similar lithologic trends, yield two distinct units: the lower and upper units reflect open marine and seaice influenced depositional environments, respectively (Fig. 3).

The lower unit of the cores comprises a laminated greenish grey silty mud overlain by a bioturbated olivegrey silty mud in the upper unit (Figs. 3, 4). The mean grain size in the lower unit of core WB2 is not only highly variable, but is also coarser, and more positively skewed, than in the upper unit (Fig. 5), which is indicative of a fluctuating depositional environment under higher energy conditions. This interpretation is supported by the anisotropy of the magnetic susceptibility of the core, which shows higher values of Fs, often used to denote bottom current intensity, in the lower unit (Fig. 5). Ellwood \& Ledbetter (1977) measured the anisotropy of magnetic susceptibility of deep-sea core sediments from the Vema Channel, through which Antarctic Bottom Water passes from the Argentine Basin to the Brazil Basin. They found that Fs is highly correlated with bottom current activity: an increase in particle alignment is caused by an increase in bottom current velocity, which corresponds to an increase in mean grain size. The higher Fs values in the lower unit of core WB2 (Fig. 5), therefore, indicate the greater influence of bottom current activity during the deposition of the laminated lower unit, compared with the deposition of the bioturbated upper unit. Moreover, the common occurrence of wellsorted, silt-rich intervals in the lower unit (Fig. 5) appears to be the result of either active sediment reworking by bottom currents or some availability of terrigenous particles. Possible terrigenous sources on the shelf include: (1) sediment-laden meltwater from a calving tidewater glacier, (2) eolian input derived from adjoining landmasses and (3) reworking of older sediments by currents (Singer \& Anderson 1984; Anderson \& Kurtz 1985). Because of the absence of graded intervals and bottom current structures (Fig. 4b), we do not believe that the increased terrigenous materials (mostly silt fractions) in the lower unit are the result of contour currents (contourite) and/or sediment gravity flow (turbidite) along the continental slope. Sediment-laden meltwater is abundant in fjords in the modern South Shetland Islands (Yoo et al. 1999), which are located in a subpolar climate regime, but it is not clear whether significant quantities of suspended sediment from the grounding-line environment, at present deeply recessed within the fjords, reaches the middle or outer shelves (Yoon et al. 1998). Many studies have reported that fine sand and/or silt-sized material settle mostly within $1-2 \mathrm{~km}$ of the glacier front within Antarctic Peninsula fjords (Domack et al. 1993; Yoon et al. 1998). Eolian input for the increased silt in the lower unit is a possibility, as discussed by Stein (1992). However, such deposition would require the concentration of aeolian material in sea ice at the core site. Based upon the ${ }^{14} \mathrm{C}$ chronology for core WB2, deposition of the lower unit occurred between 330 and 1520 years B.P., which roughly coincides with the period of sea-ice minima between 700 and 1032 years B.P. (the Medieval Warm Period) found in Granite Harbor sediment cores from East Antarctica (Leventer et al. 1993). The sea-ice minima over the core sites during this time indicate that the possibility of an aeolian origin for the increased silt fractions in the lower unit (Fig. 5a) is slight. The core sites are inferred to have been in a trough on the shelf of the 
northern South Shetland Islands, characterized by the modern existence of the Polar Slope Current (Whitworth et al. 1994), and the well-sorted, silt-rich intervals in the lower unit may be associated with the influence of this current in the past. The Polar Slope Current is a westward-flowing, cold (less than $0.0^{\circ} \mathrm{C}$ ) and dense water current that flows along the shelf of the northern South Shetland Islands, from the Weddell Sea. It is known to originate from the mixture of the ACC and Weddell Sea water mass sequences (Whitworth et al. 1994). It is thought that the Polar Slope Current would significantly intrude into the core sites during warm periods, as water exchange between the Weddell Sea and the shelf of the northern South Shetland Islands would have been well established because of the reduced sea-ice cover, or even open marine conditions. This speculation may explain the significant reworking of initially unsorted shelf sediments, and the resulting formation of a well-sorted, siltrich layer in the lower unit of the cores (Fig. 5). Enhanced biological productivity under open marine conditions would prevail around the study area at this time, resulting in the higher percentages of TOC in the lower unit, as shown in Figs. 6 and 7. Generally, the increased penetration of incident light, resulting from the reduced sea-ice cover, encourages plankton photosynthesis and, thereby, a higher level of primary productivity in the stable, meltwater-induced surface layer of the water column, as shown by the increased diatom valve concentration in the lower unit of core WB2 (Fig. 8). Both warmer surface water conditions and reduced sea-ice cover appear to have contributed to the elevated productivity around the core sites, as evidenced by the lower $\mathrm{C}: \mathrm{N}$ ratios in the lower unit, despite a warmer climate regime in which the input of terrestrial vegetation (i.e., lichen and moss debris, and algae) should increase the $\mathrm{C}: \mathrm{N}$ ratio (Figs. 6, 7).

The upper unit is bioturbated, poorly sorted and depleted in silt-rich intervals (Figs. 4a, 5), indicating sedimentation, with less hydraulic energy, in a protected environment, such as a sea-ice influenced depositional environment. The reduction of both TOC content and diatom valve concentration in the upper unit (Figs. 6-8) also reflects the changing depositional environment, from that of an open marine environment with active shelf currents to that typical of a colder environment with increased sea-ice cover. Hence, some climatic and/or oceanographic event induced cooler and icier conditions during the deposition of the upper unit. The decline in TOC content in the upper unit (Fig. 6) is probably associated with the formation of sea ice since 330 years B.P., as the onset of the upper unit corresponds to the LIA global cold event, of 600-100 years B.P. (O'Brien et al. 1995). The inferred cooling and sea-ice expansion at about 330 years B.P. in the northern Antarctic Peninsula are consistent with marine records from the Müller Ice Shelf, where the advance of the shelf took place about 400 years B.P. (Domack et al. 1995), and from the Palmer Deep in the western Antarctic Peninsula, where the seaice expansion occurred about 500 years B.P. (Domack $\delta$ Mayewski 1999).

During the cooling event, the north-western Weddell Sea would have remained ice-covered for longer during the summer. Thus, the winter restriction between the Weddell Sea and the core sites might have continued during the summer. This would have severely restrained the Weddell-South Shetland connection during summer seasons, and the Polar Slope Current of Weddell Sea water origin could not have entered the shelf of the northern South Shetland Islands. Under these conditions, it is also expected that the bioactivity of benthic animals gradually increased, resulting in the bioturbated sediment in the upper unit, as shown in Fig. 4a. However, the top $15 \mathrm{~cm}$ (approximately from the past 50 years) of core WB2, in which the TOC content increases abruptly (Fig. 6), may record recent regional warming in the Antarctic Peninsula region. This climatic amelioration could have restored the Weddell-South Shetland Islands connection during summer seasons, resulting in an intensification of the Polar Slope Current. This interpretation is supported by the dramatic increase of well-sorted silt content in the top $15 \mathrm{~cm}$ of core WB2 (Fig. 5).

\section{Palaeoceanographic implications of diatoms}

The Chaetoceros resting spore is the dominant taxa in the shelf sediment of the northern South Shetland Islands, comprising more than $20 \%$ of frustules in core WB2 (Fig. 8). They are the most common diatom species around the Antarctic Peninsula, dominating the water column, sediment trap and surface sediment diatom assemblages (Leventer 1991). The high relative abundance of Chaetoceros resting spores has usually been attributed to periods of high productivity, often associated with ice-edge blooms, where nitrate depletion leads to spore formation (Stockwell 1991; Leventer 1992, 1998). The suggestion that very high abundances of Chaetoceros resting spores are associated with ice-edge blooms is supported by the distribution of phytoplankton assemblages along a transect from the Weddell Sea MIZ through the Bransfield Strait to the offshore region off the South Shetland Islands, observed by Kang et al. (2001). They reported that the Weddell Sea MIZ is characterized by ice-edge blooms such as Chaetoceros resting spores and typical sea-ice taxa of Fragilariopsis spp., which together account for $70 \%$ of the total phytoplankton assemblage. In contrast, these diatoms were depleted in the open 
water of the Bransfield and South Shetland islands. Thus, the high Chaetoceros spore and sea-ice taxa abundances in the lower unit of core WB2 (Fig. 8) are suggestive of lateral advection of the ice-edge blooms from the Weddell Sea MIZ to the core site between 330 and 1520 years B.P., roughly coinciding with the global warm period (Leventer et al. 1993). The increased abundance of $R$. antennata in the lower unit (Fig. 8) may be related to the intrusion of the stratified cold water from the Weddell Sea, as this species is reported to be an important component in stratified water columns near the sea-ice edge (Crosta et al. 2005). The lateral transport of diatom flocs is evidenced by recent sediment trap data from the eastern Bransfield Strait. These show higher flux values for diatoms and total particles in the lower trap, compared with the upper trap (Kim et al. 2000), suggesting a lateral influx of Chaetoceros resting spores from the Weddell Sea MIZ. Nowlin \& Zenk (1988) reported that the westwardflowing Polar Slope Current, centred at a depth of $300 \mathrm{~m}$ along the northern margin of the South Shetland Islands, is a continuation of Weddell Sea water from the Weddell Sea MIZ, which would account for the advections of ice-edge blooms from the Weddell Sea MIZ.

Warming during the deposition of the lower unit (Fig. 8) would have resulted in a shorter seasonal duration of sea-ice coverage in the study area. The WeddellSouth Shetland connection would have been established for longer time spans, and larger blooms of Chaetoceros resting spores and sea-ice taxa at the sea-ice edge, and of $R$. antennata in the cold stratified water in the Weddell Sea, could then have entered the core site. This would have severely diluted the abundances of F. kerguelensis, the characteristic species of the ACC (Burckle 1987), and A. actinochilus and N. glaciei, which are indigenous to the neritic loose ice in the South Shetland Islands. This interpretation is supported by the slight decrease of these diatoms in the lower unit (Fig. 8).

The opposite trend-the decreasing abundance of Chaetoceros resting spores, sea-ice taxa and $R$. antennata in the upper unit-may have resulted from glacial restriction between the Weddell Sea and the South Shetland Islands during the LIA. During the period of maximum sea-ice extent, the north-western Weddell Sea would have been ice-covered for greater proportions of the year, or might have been ice-covered even during the summer seasons. These conditions would have suppressed the production of Chaetoceros resting spores, sea-ice taxa and $R$. antennata, as demonstrated by the reduction of biological production during the LGM in the Weddell Sea (Pudsey 1992). Only a reduced number of ice-edge blooms from the Weddell Sea MIZ entered the shelf of the northern South Shetland Islands, because of the restricted Weddell-South Shetland connection, as is shown by the decrease in the abundance of Chaetoceros resting spores, sea-ice taxa and $R$. antennata in the upper unit (Fig. 8). The abundance of Chaetoceros resting spores, sea-ice taxa and $R$. antennata in the upper unit is unlikely to have been diluted by high silisiclastic deposition: there is no increase in either sand and silt contents or mean grain size in the upper unit (Fig. 5). In contrast, the dramatic increase in the abundance of A. actinochilus and N.glaciei in the upper unit (Fig. 8) may be related to the reduced dilution of these neritic diatoms in the South Shetland Islands, resulting from the restricted Weddell Sea-South Shetland communication. It may represent deposition in an environment of loose sea ice associated with windy, cool climatic conditions during the LIA.

The foregoing discussion shows that there is strong evidence for climatic cooling at the core site during the LIA, which is a widely recognized Northern Hemisphere neoglacial event. The advance of glacial margins during the LIA is also recognized from other high-latitude regions in the Southern Hemisphere (Clapperton 1990). Marine records from the Müller Ice Shelf have demonstrated that the advance of the ice shelf took place at about 400 years B.P. (Domack et al. 1995). A study of ice-core records during the LIA indicates that the entire continent experienced a cooler climate, whereas the region in the vicinity of Siple Station, including the Antarctic Peninsula, experienced warmer temperatures at this time (Mosley-Thompson et al. 1990; MosleyThompson 1992). If the LIA was characterized by warmer conditions on the Antarctic Peninsula, then it is difficult to reconcile evidence of sea-ice expansion on the shelf of the northern South Shetland Islands with the climatic record. A warmer period would presumably be less favourable for sea-ice expansion: most of the ice shelves in the western Antarctic Peninsula are in retreat under the recent warming trend (Doake \& Vaughan 1991). It is therefore possible that conditions varied across the Antarctic Peninsula during the late Holocene, so that sea-ice extent in some areas, such as the continental shelf of the northern South Shetland Islands, increased from around 330 years B.P. as a result of a cold climate. Additional palaeoenvironmental data are needed from a diversity of locations in the Antarctic Peninsula to fully address this problem.

The top $15 \mathrm{~cm}$ of core WB2 may document a return to a warmer climate. Chaetoceros resting spores, F. curta and F. cylindrus, which are very abundant in the Weddell Sea MIZ, have increased dramatically in abundance, indicating the arrival of ice-edge blooms from the Weddell Sea MIZ at the core site, via the re-established Weddell-South Shetland communication. The marked increase of TOC content and the well-sorted silt fraction in the top $15 \mathrm{~cm}$ may also be related to the opening of this communica- 
tion. This may record recent regional warming in the Antarctic Peninsula: the signal is not strong, and more data are needed in order to draw definitive conclusions.

\section{Acknowledgements}

We are grateful for technical assistance from the crew of the RV Yuhzmorgeologiya and Suyun Im in the acquisition of data, and for early discussions with Yong Il Lee and Jong Duk Lee. This research was funded by Korea Polar Research Institute grant PE09010, and by the Ministry of Environment as the Eco-technopia 21 Project (PN08020).

\section{References}

Allen C.S., Pike J., Pudsey C.J. \& Leventer A. 2005. Submillennial variations in ocean conditions during deglaciation based on diatom assemblages from the southwest Atlantic. Paleoceanography 20, PA2012, doi: 10.1029/2004PA001055.

Anderson J.B. \& Kurtz D.D. 1985. The use of silt grain size parameters as a paleovelocity gauge: a critical review and case study. Geo-Marine Letters 5, 55-59.

Armand L.K., Crosta X., Romero O. \& Pichon J.-J. 2005. The biogeography of major diatom taxa in Southern Ocean sediments: 1. Sea ice related species. Palaeogeography, Palaeoclimatology, Palaeoecology 223, 93-126.

Barsch D. \& Mäusbacher R. 1986. New data on the relief development of the South Shetland Islands, Antarctica. Interdisciplinary Science Reviews 11, 211-218.

Berkman P.A., Andrew J.T., Bjorck S., Colhoun E.A., Emslie S.D., Goodwin I.D., Hall B.L., Hart C.P., Hirakawa K., Igarashi A., Ingolfsson O., Lopez-Martinez J., Lyons W.B., Mabin M.C.G., Quilty P.G., Taviani M. \& Yoshida Y. 1998. Circum-Antarctic coastal environmental shifts during the late Quaternary reflected emerged marine deposits. Antarctic Science 10, 345-362.

Bjorck S., Hakansson H., Zale R., Karlen W. \& Liedberg Jonsson B. 1991. A late Holocene lake sediment sequence from Livingston Island, South Shetland Islands, with paleoclimatic implications. Antarctic Science 3, 61-72.

Bjorck S., Malmer N., Hjort C., Sandgren P., Ingolfsson O., Wallen B., Lewis Smith R.I. \& Liedberg Jonsson B. 1991. Stratigraphic and paleoclimatic studies of a 5500-year-old moss bank on Elephant Island, Antarctica. Arctic and Alpine Research 23, 361-374.

Burckle L.H. 1987. Diatom distribution in the Weddell gyre region during the late winter. Micropaleontology 33, 177-184.

Clapperton C.M. 1990. Quaternary glaciations in the Southern Ocean and Antarctic Peninsula area. Quaternary Science Reviews 9, 229-252.

Clapperton C.M. \& Sugden D.E. 1989. Holocene glacier fluctuations in South America and Antarctica. Quaternary Science Reviews 7, 185-198.
Crosta X., Romero O., Armand L.K. \& Pichon J.-J. 2005. The biogeography of major diatom taxa in Southern Ocean sediments: 2. Open ocean related species. Palaeogeography, Palaeoclimatology, Palaeoecology 223, 66-92.

Crosta X., Sturm A., Armand L. \& Pichon J.J. 2004. Late Quaternary sea ice history in the Indian sector of the Southern Ocean as recorded by diatom assemblages. Mar. Micropaleontology 50, 209-223.

Cunningham W.L., Leventer A. 1998. Diatom assemblages in surface sediments of the Ross Sea: relationship to present oceanographic conditions. Antarctic Science 10, 134-146.

DeMaster D.J. \& Cochran J.K. 1982. Particle mixing rates in deep-sea sediments determined from excess ${ }^{210} \mathrm{~Pb}$ and ${ }^{32} \mathrm{Si}$ profiles. Earth and Planetary Science Letters 61, 257-271.

Doake C.S.M. \& Vaughan D.G. 1991. Rapid disintegration of the Wordie Ice Shelf in response to atmospheric warming. Nature 350, 328-330.

Domack E.W. \& Ishman S.E. 1993. Oceanographic and physiographic controls on modern sedimentation within Antarctic fjords. Geological Society of America Bulletin 105, 1175-1189.

Domack E.W., Ishman S.E., Stein A.B., McClennen C.E. \& Jull A.T. 1995. Late Holocene advance of the Müller Ice Shelf, Antarctic Peninsula: sedimentological, geochemical and palaeontological evidence. Antarctic Science 7, 159-170.

Domack E.W., Jull A.J.T., Anderson J.B., Linick T.W. \& Williams C.R. 1989: Application of tandem accelerometer mass-spectrometer dating to late Pleistocene-Holocene sediments of the East Antarctic continental shelf. Quaternary Research 31, 277-278.

Domack E.W., Jull A.J.T. \& Nakao S. 1991. Advance of East Antarctic outlet glaciers during the Hypsithermal: implications for the volume state of the Antarctic ice sheet under global warming. Geology 19, 1059-1062.

Domack E.W., Leventer A., Dunbar R., Taylor F., Brachfeld S., Sjunneskog C. \& ODP Leg 178 Scientific Party 2001. Chronology of the Palmer Deep site, Antarctic Peninsula: a Holocene paleoenvironmental reference for the circum-Antarctic. Holocene 11, 1-9.

Domack E.W., Mashiotta T.A., Burkley L.A. \& Ishman S.E. 1993. 300-year cyclicity in organic matter preservation in Antarctic fjord sediments. Antarctic Research Series 60 , 265-272.

Domack E.W. \& Mayewski P.A. 1999. Bi-polar ocean linkages: evidence from late-Holocene Antarctic marine and Greenland ice-core records. Holocene 9, 247-251.

Ellwood B.B. 1975. Analysis of emplacement mode in basalt from deep-sea drilling project holes 319A and 321 using anisotropy of magnetic susceptibility. Journal of Geophysical Research 80, 4805-4808.

Ellwood B.B. \& Ledbetter M.T. 1977. Antarctic bottom water fluctuations in the Vema Channel: effects of velocity changes on particle alignment and size. Earth and Planetary Science Letters 35, 189-198.

Folk R.L. \& Ward W.C. 1957: Brazos river bars: a study in the significance of grain size parameters. Journal of Sedimentary Petrology 27, 3-26. 
Fryxell G.A., Kang S. \& Reap M. 1987. AMERIEZ 1986: phytoplankton at the Weddell Sea ice edge. Antarctic Journal of the United States 22, 173-175.

Fryxell G.A. \& Kendrick G.A. 1988. Austral spring microalgae across the Weddell Sea ice edge: spatial relationships found along a northward transect during AMERIEZ 83. Deep-Sea Research Part I 35, 1-20.

Gibson J.A.E., Trull T., Nichols P.D., Summons R.W. \& McMinn A. 1999. Sedimentation of ${ }^{13} \mathrm{C}$-rich organic matter from Antarctic sea-ice algae: a potential indicator of past sea ice extent. Geology 27, 331-334.

Grove J.M. 1988. The Little Ice Age. New York: Methuen.

Gordon J.E. \& Harkness D.D. 1992. Magnitude and geographic variation of the radiocarbon content in Antarctic marine life: implications for reservoir corrections in radiocarbon dating. Quaternary Science Reviews 11, 697-708.

Hofmann E.E., Lascara C.M. \& Klinck J.M. 1992. Palmer LTER: upper-ocean circulation in the LTER region from historical sources. Antarctic Journal of the United States 27, 239-241.

Ichii T., Katayama K., Obitsu N., Ishii H. \& Naganobu M. 1998. Occurrence of Antarctic krill (Euphausia superba) concentrations in the vicinity of the South Shetland Islands: relationship to environmental parameters. Deep-Sea Research Part I 45, 1235-1262.

Ingolfsson O., Hjort C., Berkman P.A., Bjorck S., Colhoun E., Goodwin I.D., Hall B., Hirakawa K., Melles M., Moller P. \& Prentice M.L. 1998. Antarctic glacial history since the Last Glacial Maximum: an overview of the record on land. Antarctic Science 10, 326-345.

Jones K.P.N., McCave I.N. \& Patel P.D. 1988. A computer-interfaced sedigraph for modal size analysis of fine-grained sediment. Sedimentology 35, 163-172.

Kang S.H., Kang J.S., Lee S., Chung K.H., Kim D. \& Park M.G. 2001. Antarctic phytoplankton assemblages in the marginal ice zone of the northwest Weddell Sea. Journal of Plankton Research 23, 333-352.

Kang J.S., Kang S.H., Lee J.H. \& Lee S.H. 2002. Seasonal variation of microalgal assemblages at a fixed station in King George Island, Antarctica, 1996. Marine Ecolology Progress Series 229, 19-32.

Kim D., Kim D.-Y., Shim J.-H. \& Kang S.H. 2000. Particle flux in the eastern Bransfield Strait, Antarctica. Korea Ocean Research and Development Institute Open File Report, BSPP00001-05-1329-7, 57-70.

Kozlova A.P. 1966: Diatom algae of the Indian and Pacific sectors of Antarctica. Moscow: Institute of Oceanology, Academy of Sciences of the USSR.

Lamb F.F. 1977. Climate: present, past and future. Vol. 2. Climatic history and the future. London: Methuen.

Leventer A. 1991. Sediment trap diatom assemblages from the northern Antarctic Peninsula region. Deep-Sea Research Part I 38, 1127-1143.

Leventer A. 1992. Modern distribution of diatoms in sediments from George V Coast, Antarctica. Marine Micropaleontology 19, 315-332.
Leventer A. 1998. The fate of Antarctic "sea ice diatoms" and their use as paleoenvironment indicators. Antarctic Research Series 73, 121-137.

Leventer A. \& Dunbar R.B. 1996. Factors influencing the distribution of diatoms and other algae in the Ross Sea. Journal of Geophysical Research-Oceans 101(C8), 18 489-18 500.

Leventer A., Dunbar R.B. \& DeMaster D. 1993. Diatom evidence for late Holocene climatic events in Granite Harbor, Antarctica. Paleoceanography 8, 373-386.

Mäusbacher R., Muller J., Munnich M. \& Schmidt R. 1989. Evolution of postglacial sedimentation in Antarctic lakes (King George Island). Zeitschrift fur Geomorphologie, N.F. 33, 219-234.

Medlin L. \& Priddle J. 1990. Polar marine diatoms. Cambridge: British Antarctic Survey.

Mosley-Thompson E. 1992. Paleoenvironmental conditions in Antarctica since A.D. 1500: ice core evidence. In R.S. Brandley \& P.D. Jones (eds.): Climate since A.D. 1500. Pp. 572-591. London: Routledge.

Mosley-Thompson E. \& Thompson L.G. 1982. Nine centuries of microparticle deposition at the South Pole. Quaternary Research 17, 1-13.

Mosley-Thompson E., Thompson L.G., Groots P.M. \& Gunderstrup N. 1990. Little Ice Age (Neoglacial) paleoenvironmental conditions at Siple Station, Antarctica. Annals of Glaciology 14, 199-204.

Nowlin W.D. \& Zenk W. 1988. Westward bottom currents along the margin of the South Shetland Islands arc. Deep-Sea Research Part I 35, 269-301.

O'Brien S.R., Mayewski P.A., Meeker L.D., Meese D.A., Twickler M.S. \& Whitlow S.I. 1995. Complexity of Holocene climate as reconstructed from a Greenland Ice Core. Science 270, 1962-1964.

Park B.-K., Chang S.-K., Yoon H.I. \& Chung H.S. 1998. Recent retreat of ice cliffs, King George Island, South Shetland Islands, Antarctic Peninsula. Annals of Glaciology 27, 633-635.

Pudsey C.J. 1992. Late Quaternary changes in Antarctic Bottom Water velocity inferred from sediment grain size in the northern Weddell Sea. Marine Geology 107, 9-33.

Pudsey C.J. \& Evans J. 2001. First survey of Antarctic sub-ice shelf sediments reveals mid-Holocene ice shelf retreat. Geology 29, 787-790.

Scherer R.P. 1994. A new method for the determination of absolute abundance of diatoms and other silt-sized sedimentary particles. Journal of Paleolimnology 12, 171-179.

Schmidt R., Mausbacher R. \& Muller J. 1990. Holocene diatom flora and stratigraphy from sediment cores of two Antarctic lakes (King George Island). Journal of Paleolimnology 3, 55-74.

Schrader H.J. \& Gersonde R. 1978. Diatoms and silicoflagellates. Utrecht Micropaleontological Bulletin 17, 129-176.

Shevenell A.E, Domack E.W. \& Kernan G.M. 1996. Record of Holocene paleoclimate changes along the Antarctic Peninsula: evidence from glacial marine sediments, 
Lallemand Fjord. Papers and Proceedings of the Royal Society of Tasmania 130, 55-64.

Singer J.K. \& Anderson J.B. 1984. Use of total grain-size distributions to define bed erosion and transport for poorly sorted sediment undergoing simulated bioturbation. Marine Geology 57, 335-359.

Smith B.M.E. 1972. Airborne radio echo soundings of glaciers in the Antarctic Peninsula. British Antarctic Survey Science Report 72. Cambridge: British Antarctic Survey.

Stein A.B. 1992. Growth of the Müller Ice Shelf during the later half of the Little Ice Age as documented by glacial marine sediments and radiogeochemistry. BA thesis, Hamilton College, Clinton, NY.

Stockwell D.A. 1991. Distribution of Chaetoceros resting spores in the Quaternary sediments from Leg 119. Proceedings of the Ocean Drilling Program, Scientific Results 119, 599-610.

Thompson L.G., Mosley-Thompson E., Dansgaard W. \& Grootes P.M. 1986. The Little Ice Age as recorded in the stratigraphy of the tropical Quelccaya Ice Cap. Science 234, 361-354.

Tokarczyk R. 1987. Classification of water masses in the Bransfield Strait and southern part of the Drake Passage using a method of statistical multidimensional analysis. Polish Polar Research 8, 333-366.

Tortell P.D., Reinfelder J.R. \& Morel F.M.M. 1997. Active uptake of biocarbonate by diatoms. Nature 390, 243-244.

Villareal T.A. \& Fryxell G.A. 1983. The diatom genus Porosira Jorg: cingulum patterns and resting spore morphology. Botanica Marina 33, 415-422.
Whitworth T. III, Nowlin W.D., Orsi A.H., Locarnini R.A. \& Smith S.G. 1994. Weddell Sea Shelf water in the Bransfield Strait and Weddell-Scotia Confluence. Deep-Sea Research Part I 41, 629-641.

Yoo K.C., Yoon H.I., Oh J.-K., Kim Y. \& Kang C.Y. 1999. Water column properties and dispersal pattern of suspended particulate matter (SPM) of Marian Cove during austral summer, King George Island, West Antarctica. Journal of the Korean Society of Oceanography 4, 266-274.

Yoon H.I., Han M.W., Park B.-K., Oh J.-K. \& Chang S.-K. 1997. Glaciomarine sedimentation and paleo-glacial setting of Maxwell Bay and its tributary embayment, Marian Cove, South Shetland Islands, West Antarctica. Marine Geology 140, 265-282.

Yoon H.I., Park B.-K., Domack E.W. \& Kim Y. 1998. Distribution and dispersal pattern of suspended particulate matter in Maxwell Bay and its tributary, Marian Cove, in the South Shetland Islands, West Antarctica. Marine Geology 152, 261-275.

Yoon H.I., Park B.-K., Kim Y. \& Kang C.Y. 2002. Glaciomarine sedimentation and its paleoclimatic implications on the Antarctic Peninsula shelf over the last 15000 years. Palaeogeography, Palaeoclimatology, Palaeoecology $185,235-254$.

Yoon S.H., Yoon H.I. \& Kang C.Y. 2004. Late Quaternary sedimentary processes in the northern continental margin of the South Shetland Islands, Antarctica. Journal of the Korean Society of Oceanography 9, 1-12. 